\title{
Financial inclusion and extreme poverty in the MENA region: a gap analysis approach
}

\author{
Noha Emara
}

\author{
Department of Economics, Faculty of Arts and Sciences, Rutgers University \\ Camden, Camden, New Jersey, USA and Department of Economics, \\ Helwan University, Cairo, Egypt, and \\ Mahmoud Mohieldin \\ Special Envoy on Financing the 2030 Agenda, United Nations
}

\begin{abstract}
Purpose - Eradicating extreme poverty remains one of the most significant and challenging sustainable development goals (SDGs) in the Middle East and North African (MENA) region. The latest World Bank statistics from 2018 show that extreme poverty in MENA increased from 2.6\% to 5\% between 2013 and 2015. MENA ranks third among developing regions for extreme poverty and fell short of halving extreme poverty by 2015 - the target established by the United Nations' (UN) millennium development goals, the precursor to the SDGs. The purpose of this study is to analyze the impact of financial inclusion on extreme poverty for a sample of 34 countries over the period 1990-2017.

Design/methodology/approach - Using system general method of moments dynamic panel estimation methodology on annual data for 11 MENA countries and 23 emerging markets (EMs) over the period 1990 2017, this study begins by estimating the impact of financial inclusion - using measures of access and usage on the eradication of extreme poverty by 2030, the first goal of the SDGs.

Findings - The results of the study indicate that, on one hand, financial access measures have a positive, statistically significant impact on reducing extreme poverty for the full sample and the MENA region. The second part of the study uses a gap analysis against four poverty targets $-0 \%, 1.5 \%, 3 \%$ and $5 \%-$ and shows that no MENA country and few EM countries will be able to close the extreme poverty gap and reach the target of $0 \%$ by 2030 by depending solely on improvements in financial access. These targets are based on the two benchmarks set by the World Bank and the UN, with intermediaries to capture error and give a fuller picture of what is possible. However, if improvements in financial inclusion alone can bring every EM and MENA country except Djibouti and Romania to bring the most accessible target of reducing global extreme poverty to no more than $5 \%$ by 2030 .

Originality/value - While research on poverty reduction in the region tends to focus on financial development and governance, less attention has been paid to the role of financial inclusion. SDG 1 eliminating poverty in all its forms - explicitly highlights the importance of access to financial services. Indeed, evidence from Argentina, India, Kenya, Malawi, Niger and other countries demonstrates the ways in which financial inclusion can impact poverty (Klapper, El-Zoghbi and Hess, 2016). When people are included in the financial system, they are better able to improve their health, invest in education and business and make choices that benefit their entire families. Financial inclusion advances governments, too: introducing
\end{abstract}

(C) Noha Emara and Mahmoud Mohieldin. Published in Review of Economics and Political Science. Published by Emerald Publishing Limited. This article is published under the Creative Commons Attribution (CC BY 4.0) licence. Anyone may reproduce, distribute, translate and create derivative works of this article (for both commercial and non-commercial purposes), subject to full attribution to the original publication and authors. The full terms of this licence may be seen at http:// creativecommons.org/licences/by/4.0/legalcode

JEL classification - C23, G21, O43

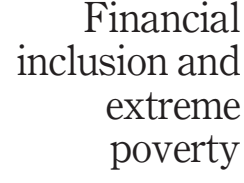

207

Received 27 March 2020 Revised 6 April 2020 Accepted 5 May 2020 
REPS

5,3

\section{8}

vast segments of the population into the financial system by digitizing social transfers, for example, can cut government costs and reduce leakage, with benefits that ripple across society. Yet, the links between financial inclusion and poverty reduction in MENA are less established. This study aims to analyze the importance of financial inclusion in addressing extreme poverty by 2030, the year UN member states set as a target for achieving the SDGs.

Keywords Financial inclusion, Extreme poverty, Gap approach, MENA region SDGs

Paper type Research paper

\section{Introduction}

The world has made remarkable progress reducing extreme poverty in the past 25 years. Between 1990 and 2015, the number of people living on less than $\$ 1.90$ per day - the international benchmark for extreme poverty - dropped by one billion, bringing us closer to the United Nations (UN) sustainable development goals (SDGs). Still, the benefits of economic growth have reached regions, countries and individuals unevenly. An unacceptably large number of people, more than 700 million, still live in poverty across the globe and extreme poverty is becoming more entrenched in some places, especially those fraught by violent conflicts and weak institutions.

In the Middle East and North Africa (MENA), a region particularly vulnerable to fragility, eradicating extreme poverty remains one of the most challenging of the SDGs [1]. MENA ranks third among developing regions for extreme poverty. According to the latest World Bank data, the proportion of the population living under $\$ 1.90$ a day rose from $2.6 \%$ to $5 \%$ between 2011 and 2015 , while the number of poor nearly doubled from 9.5 to 18.6 million over the same period as shown in Figures 1 and 2. Although extreme poverty is much higher in sub-Saharan Africa (SSA), the pace at which it is growing in MENA presents a blunt warning that progress cannot be taken for granted. The erosion of past gains risks fueling political, economic and environmental crises, threatening to exacerbate the circumstances of those already struggling to protect their lives and livelihoods.

Despite the fact that financial access has improved dramatically worldwide, the MENA region still lags behind in measures of financial access. Figures 3 and 4 shows the state of the three measures of financial access in different regions of the world. As shown in Figure 3, for the MENA region, the number of automated teller machines (ATMs) per

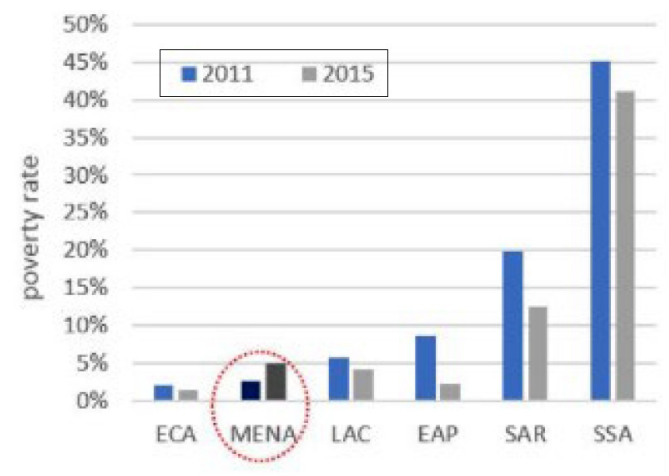

Source: 2018 poverty and shared prosperity report: piecing together the poverty puzzle. World Bank
Figure 1.

Extreme poverty rates at US $\$ 1.92011$ ppp line cross regions in 2011 and $2015, \%$ 


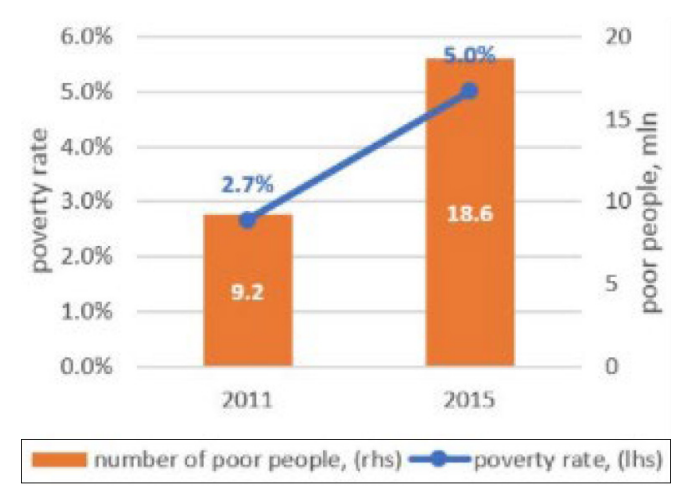

Source: 2018 poverty and shared prosperity report: piecing together the poverty puzzle. World Bank

\section{Financial inclusion and extreme poverty}

209

Figure 2.

Extreme poverty rates and absolute number of extreme poor at US\$1.9 2011 ppp line in MENA

100,000 Adults grew by about 125\% over the period from 2011-2018, however, the region only surpasses South Asia and SSA regions. Additionally, over the same period the number of commercial bank branches per 100,000 adults has also increased, albeit at a lower growth rate than that of ATMs, by about 56\% ranking the region third highest among the six regions in 2018. Figure 4 shows that the number of bank accounts as a $\%$ of the population, is relatively low level that is barely surpassing that of SSA region in 2017.

While research on poverty reduction in the region tends to focus on financial development, less attention has been paid to the role of financial inclusion. SDG 1 [2] eliminating poverty in all its forms - explicitly highlights the importance of access to financial services. Indeed, evidence from Argentina, India, Kenya, Malawi, Niger and other countries demonstrates the ways in which financial inclusion can impact poverty (Klapper et al., 2016). When people are included in the financial system, they are better able to improve their health, invest in education and business and make choices that benefit their entire families. Financial inclusion advances governments, too: introducing vast segments of the population into the financial system by digitizing social transfers, for example, can cut government costs and reduce leakage, with benefits that ripple across society.

Yet, the links between financial inclusion and poverty reduction in MENA are less established. This study aims to analyze the importance of financial inclusion in addressing extreme poverty by 2030, the year UN member states set as a target for achieving the SDGs. We assess improvements in financial inclusion against four targets of $0 \%, 1.5 \%, 3 \%$ and $5 \%$ living in poverty [3]. In so doing, this study seeks to answer the following questions: Do different types of financial inclusion indicators (focusing on those for access) affect poverty alleviation directly? Is this effect the same across samples of MENA countries and emerging markets (EMs) more broadly? Are the countries under study able to use financial inclusion tools exclusively to close the poverty gap by 2030? The remainder of the paper is divided as follows: Section 2 briefly reviews the literature; Section 3 describes the data used; Section 4 highlights the methodology used and the model specification; Section 5 presents our results; and Section 6 concludes. An Appendix appears at the end of the paper.

\section{Literature review}

When the World Bank called for an end to extreme poverty by 2030 and the UN set a more ambitious goal to eliminate poverty in all its forms, everywhere, progress from the previous 


\section{REPS}

5,3

\section{0}

\section{Figure 3.}

ATMs and

commercial bank

branches (per 100,000

Adults), 2011-2018

\section{Figure 4.}

Accounts $(\%$, ages 15+), 2011-2017
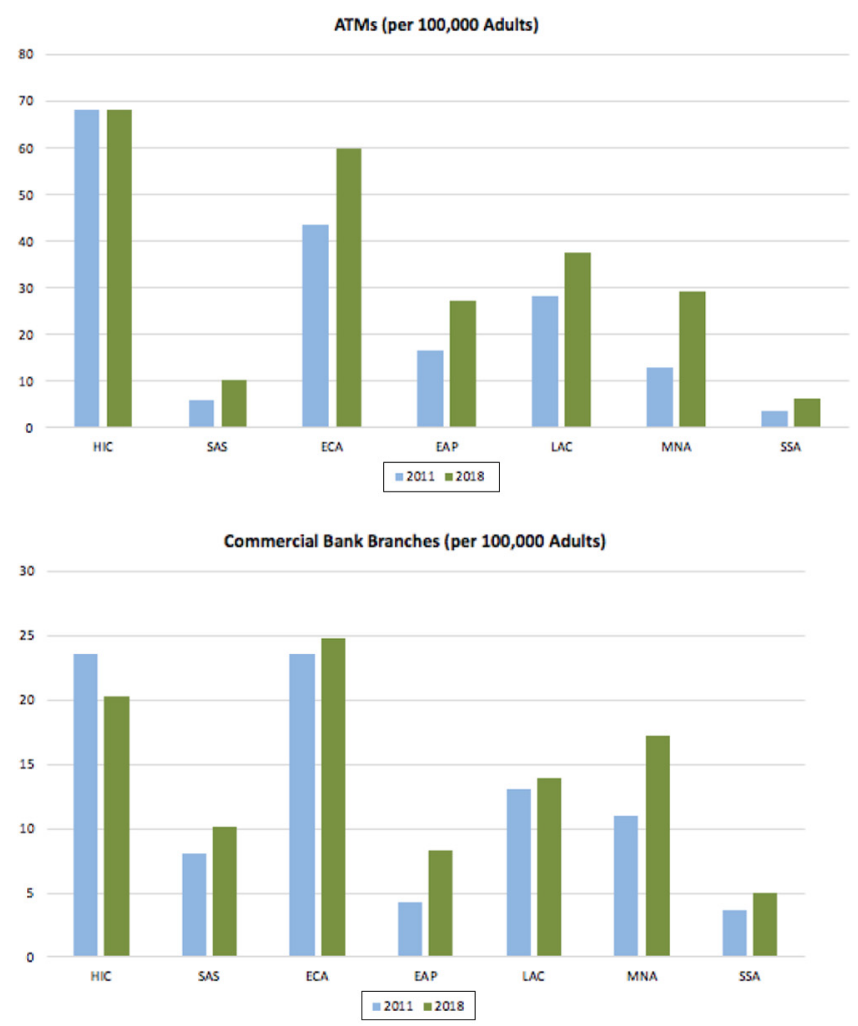

Notes: High income (HIC); South Asia (SAS); Europe and Central Asia (ECA); East Asia and Pacific (EAP); Latin America and Caribbean (LAC); Middle East and North Africa (MNA); Sub-Saharan Africa (SSA)

Accounts (\%, ages 15+), 2011-2017

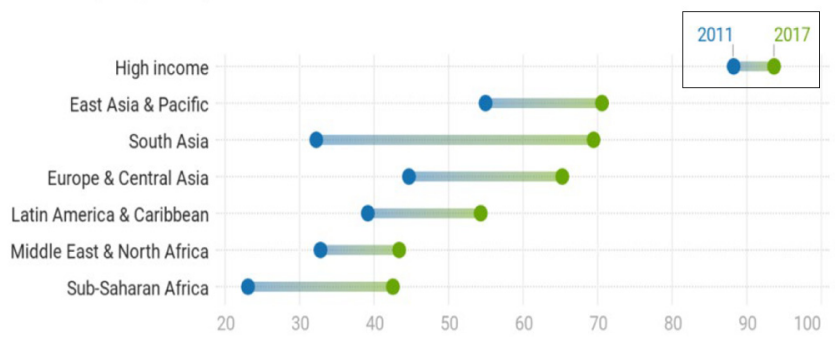

Source: Global financial inclusion database 
two decades had given the international community reason to be hopeful. More than a third of the world lived in extreme poverty in 1990, by 2015, the ratio had fallen to one tenth (World Bank, 2018). However, the pace of poverty reduction has slowed and for millions of people in SSA and MENA, poverty is on the rise. The 2015 figure proved the low point.

Over the past several years, researchers have used various dimensions of financial inclusion to point to the causal relationship between financial inclusion and economic growth (Honohan, 2004; Demirguc-Kunt and Klapper, 2013; Cumming et al., 2014; Klapper et al., 2016; El-Zhoghbi et al., 2019). A study in India found measures such as banking penetration, deposits and availability and use of banking services boosted growth between 2004 and 2013 (Sharma, 2016). Another in Kenya estimated that the expansion of a mobile money service significantly contributed to per-capita income growth (Beck et al., 2018). Then, in countries in the MENA region, scholars have demonstrated the impact of financial development (Hamdi and Hakimi, 2015), banking concentration (Abuzayed and Fayoumi, 2016) and households' financial access (Emara and El Said, 2020) on growth.

When it comes to countries in MENA, the link between financial inclusion and the poor is no clearer. Indeed, many researchers turn elsewhere to understand poverty in the region. Banerji and Humphreys (2003) focus on good governance as a crucial component of poverty relief, while Ncube et al. (2013) find that domestic investment, trade openness, exchange rates, income per capita, and oil rents are key poverty-reducing variables. Neaime and Gaysset (2018) use general method of moments (GMM) and generalized least squares models to conclude that population, inflation and trade openness have significant effects on poverty, whereas financial inclusion does not appear to alleviate it.

Still, it is increasingly recognizing that lack of access to finance in MENA is a severe restriction on economic growth and poverty alleviation, as the poor struggle to accumulate savings and cover critical health and education expenses (Alvarez de la Campa, 2010; Pearce, 2011). The region lags others on key indicators of bank deposits and loan accounts and despite the expansion of bank branches and microfinance institutions in some MENA countries, vast segments of the population are still cut off from financial services (Pearce, 2011). The limited availability and quality of data, especially as it relates to financial technology, remains another challenge to poverty-reduction efforts in MENA.

Our paper seeks to build upon this evidence base. By using access measures of financial inclusion, we contribute to the growing literature that investigates the direct link between financial inclusion and poverty reduction, with a focus on MENA countries and EMs. We use system GMM dynamic panel estimation methodology on annual data for 11 MENA countries and 23 EMs. We conclude with a gap analysis, which follows Panda and GaneshKumar (2007) method for calculating the difference between specified targets and projections in the context of achieving the millennium development goals (MDGs; Section 6). Such an analysis requires projecting global poverty to 2030 under various assumptions.

Researchers at the World Bank group recently showed, setting specifications such as household welfare growth, economic growth and inequality to "nowcast" poverty data from 2015 household surveys to the present and then project rates to 2030. Crespo Cuaresma et al. (2018) present another econometric tool for forecasting poverty rates. Their model combines country-specific historical estimates of income distribution, using Beta-Lorenz Curves with projections for changes in GDP and population demographics to create "poverty paths," by country, up to 2030 (2018).

\section{Data}

The data set is constructed as a panel of country observations from the world development indicators of the World Bank's database. The time period of the study is selected based on

\section{Financial inclusion and extreme poverty}


REPS

5,3

availability and consistency of data across countries. Additionally, given the similarities between EMs and MENA countries in the fact that their economies are comprised of sectors that have significant growth potentials, the EMs are chosen as a sample comparator. Thus, the data set encompasses 34 EMs and MENA countries over the period 1990-2017. The list of countries included in the sample is reported in Tables A1 and A2 of the Appendix.

The dependent variable in the model is the poverty headcount ratio at $\$ 1.90$ a day as a percentage of the population. The set of explanatory variables contains common determinants of poverty, including real GDP per capita growth rate, inflation rate, trade as a percentage of GDP, mobile subscription per 100 people, population growth and financial inclusion indicators covering different financial access dimensions.

The measures of financial access include the number of bank accounts per 1,000 adults, the number of commercial bank branches per 100,000 adults and the number of ATMs per 100,000 adults. The list of variables used in the study is reported in Tables A3 and A4 of the Appendix.

\section{Model specification and methodology}

Using system GMM dynamic panel estimation methodology on annual data for 11 MENA countries and 23 EMs over the period 1990-2017, the first part of the study estimates the role of financial inclusion - using measures of access - in eradicating extreme poverty (the first goal of SDG). To perform such an analysis, the following dynamic panel regression methodology is used:

$$
\operatorname{Pov}_{i, t}=\alpha+\rho \operatorname{Pov}_{i, t-1}+\beta X_{i, t}+\delta F I_{i, t}+\varepsilon_{i, t}
$$

$i=1,2, \ldots, N, t=1990, \ldots, T$

Where $P o v_{i t}$ denotes the Poverty headcount ratio at $\$ 1.90$ a day as a $\%$ of the population of country $i$, at time $t, \operatorname{Pov}_{i t-1}$ is the lagged poverty variable and $X_{i t-1}$ is the vector of explanatory variables. These include the annual GDP growth rate, inflation rate, trade as a percentage of GDP, mobile cellular subscriptions per 100 people and the annual population growth rate. The variable $F I_{i t-1}$ represents financial inclusion indicators that cover different financial access areas of the financial system in country $i$ at time $t$ and $\varepsilon_{i t}$ is the error term.

To avoid the correlation problems, following Yafee (2003) equation (1) is estimated using the GMM estimator, which consistently estimates the dynamic panel data model (Kitazawa, 2003). Arellano and Bover (1995), Blundell and Bond (1998) and Blundell et al. (2000) propose that dynamic panel system GMM (Caselli et al., 1996; Holtz-Eakin et al., 1988) is the best way to estimate economic growth models because it overcomes the bias problems of the difference GMM methodology.

The system GMM combines equation (1) with equation (2), which is simply the first difference of equation (1), to eliminate the country-specific or unobserved effect as suggested by Arellano and Bond (1991):

$$
\begin{aligned}
\left(\operatorname{Pov}_{i, t}-\operatorname{Pov}_{i, t-1}\right)= & \alpha+\rho\left(\operatorname{Pov}_{i, t-1}-\operatorname{Pov}_{i, t-2}\right)+\beta\left(X_{i, t}-X_{i, t-1}\right) \\
& +\delta\left(F I_{i, t}-\delta F I_{i, t-1}\right)+\left(\varepsilon_{i, t}-\varepsilon_{i, t-1}\right)
\end{aligned}
$$

As explained in detail in Emara and El Said (2015), The System GMM assumes two extra assumptions over the difference GMM. To ensure a zero correlation between the right-hand side variable and the list of regressors with the unobserved countries' fixed effects, two additional assumptions are added as follows, 


$$
\begin{gathered}
\mathrm{E}\left[\triangle P o v_{i, t} \varepsilon_{i, t}\right]=0, \text { For } \mathrm{t}=2, \ldots, \mathrm{T} \\
\mathrm{E}\left[\triangle M_{i, t} \varepsilon_{i, t}\right]=0, \text { For } \mathrm{t}=2, \ldots, \mathrm{T}
\end{gathered}
$$

where $M_{i, t}$ is the set of all the explanatory variables of equation (1) or $X_{i, t}$ and $F I_{i, t}$.

Next, a dummy variable for the countries of the MENA is added to the model to estimate the impact of financial inclusion in the MENA region. The model compares how the changes in access to finance affect the changes in the growth of per capita of real GDP in the MENA region with their effect in other countries. To do so we add a dummy for MENA countries along with an interaction term to the model as follows,

$$
\operatorname{Pov}_{i, t}=\alpha+\rho \operatorname{Pov}_{i, t-1}+\beta X_{i, t}+\delta F I_{i, t}+\theta M E N A_{i, t}+\varphi\left(M E N A_{i} * F I_{i, t}\right)+\varepsilon_{i, t}
$$

where MENA $_{i}$ represents the dummy variable, which takes 1 if country $i$ is a MENA country and zero if not. The total effect of the impact of the different areas of financial inclusion is estimated by adding the coefficient $\theta$ to the coefficient $\varphi$ and the statistical significance of the effect is estimated using the standard errors of these two coefficients.

The last part of the estimation methodology involves performing a gap analysis on the ability of the MENA and EM countries to achieve the extreme poverty goal by the year 2030 by depending only on the improvement in financial services and no other factors. Using the estimated $\delta$ and $\varphi$ coefficients of equation (4), the $\%$ of the population living under $\$ 1.90$ a day is projected for the year 2030. Applying Panda and Kumar's methodology for projection (2007) - also used in Emara (2014) and Emara and Moore (2014) - we proceed in four main steps. The first step entails specifying the 2030 target level of the SDG indicator under consideration or SDG1 in this study.

In the second step required growth for the SDG1 for each country is computed using a compound growth rate formula as follows:

$$
r=\left[\left(\frac{\text { Pov }_{2030}}{\text { Povl }_{l}}\right)^{1 /(2030-k)}-1\right]
$$

where $r$ is the required poverty head count ratio growth rate as defined by the $\%$ of the population living under $\$ 1.90, \operatorname{Pov}_{2030}$ is the poverty head count ratio in the year 2030, Pov is the poverty head count ratio in the latest available year and $k$ is the year of the latest available value of the poverty measure.

Next, the actual growth in the financial access indicator or FinAcc, as measured by the principal component analysis of ATMs per 100,000 adults, bank accounts per 1,000 adults and bank branches per 100,000 adults, is calculated using the following semi log trend function:

$$
\text { FinAcc } c_{t}=a+b t \text {, }
$$

where $a$ is the constant of the regression and $b$ is the growth rate in the access indicator.

The coefficients of equation (6) are estimated using time series regression for each country in the MENA sample in a turn. The next step entails using the coefficient $\varphi$ of 
REPS

5,3

\section{4}

equation (4) together with the parameter $b$ of equation (6) to project extreme poverty $\%$ in the year 2030 as follows:

$$
\operatorname{Pov}_{2030}=\operatorname{Pov}_{l}(1+b(\delta+\varphi))^{2030-k}
$$

Hence, re-writing equation (7), the growth rate of the financial access indicator, that is, required to close the poverty gap by the year 2030 is computed as follows:

$$
b_{\text {req }}=\left[\left(\frac{\text { Pov }_{2030}}{P o v_{l}}\right)^{1 /(2030-k)}-1\right] \div(\delta+\varphi)
$$

The projected 2030 value of the poverty head count ratio, Pov 2030 , computed using equation (7), is assumed to depend solely on the improvement in the financial access services. The difference between the targeted 2030 value of the projected poverty level and the targeted 2030 poverty level, which can be bridged by other non-financial factors affecting poverty such as economic growth, inflation rate, openness of the economy, population growth or the spillover effects of financial inclusion on other SDGs that are expected to reduce extreme poverty (Section 2).

Accordingly, using the results of equation (5), an SDG gap analysis is undertaken to compute and analyze the difference between the targeted and the projected values for the poverty head count ratio and a financial access gap analysis to compute the growth in the financial access indicator required to close the extreme poverty gap by the year 2030 if the group of countries in our sample depend solely on improvement in financial access services.

\section{Estimation results}

Table A5 presents the estimation results using equation (1) as the base model. The poverty variable is regressed on the set of five explanatory variables, namely GDP growth rate, inflation rate, trade, population growth rate, mobile subscription and the lagged poverty variable or the autoregressive (AR)(1) term. The first column shows the results of a regressing poverty on its own lag only. The results show an $\mathrm{AR}(1)$ coefficient of the poverty head count ratio of $0.94 \%$ of the population, representing a short-term positive correlation between poverty and its own lag.

Adding GDP growth rate to the model, Column 2 shows results. The inclusion of this variable does not have a large impact on the sign or significance of the AR(1) coefficient. The coefficient for the GDP growth rate is negative as expected and is statistically significant where a $1 \%$ increase in GDP growth rate results in a drop in the poverty head count ratio by about $0.081 \%$ of population.

As shown in Column 3, adding inflation rate alters neither the sign nor the statistical significance of the previous two regressors. However, as the results show, the coefficient of inflation rate does not have a statistically significant impact on the poverty head count ratio in any of the six regressions of this table.

Column 4 shows the results of the regression that adds population growth rate. Adding this regressor does not significantly affect the coefficients of the included regressors. The coefficient for the population growth rate is statistically significant and positive as expected where a $1 \%$ increase in the population growth rate results in an increase in the poverty head count ratio by about $0.19 \%$ of population.

Next, Column 5 includes the variable trade as a \% of GDP and shows that the addition of this variable does not significantly affect the coefficients and the statistical significance of 
the previously included regressors. The results show that the coefficient of the trade variable is positive and statistically significant as expected where a $1 \%$ increase of trade increases the poverty head count ratio by about $0.3 \%$ of population.

The final regression of the table adds the variable mobile cellular subscription (per 100 people), as presented in Column 6. The coefficient for this variable is negative and statistically significant as expected and is interpreted as indicating an increase in mobile subscription by a 100 people reduces the poverty head count ratio by about $0.002 \%$ of the population. Again, the inclusion of this variable does not have a significant impact on included coefficients for the lagged poverty, GDP growth rate, inflation rate, trade as a $\%$ of GDP and population growth rate. None of the results of the regressions show significant evidence of serial correlation in the first-differenced errors at order two. Additionally, the output of the Hansen test confirms that the set of instruments used is exogenous.

To analyze the impact of access to financial services on the poverty head count ratio, Table A6 provides the estimation results of equation (4), which adds the measures of financial inclusion to the baseline regression. The access measures cover three main variables, namely, the number of ATMs per 100,000 adults ( $\mathrm{atm}$ ), the number of bank branches per 100,000 adults $(b b)$ and the number of depositors with commercial banks per 1,000 adults $(b a)$. Column 1 shows the results of the full sample for the first access indicator, ATMs machines, which has a statistically significant negative impact on the poverty head count ratio, where a one unit increase in ATMs leads to a fall in the poverty head count ratio by about $0.64 \%$ of the population. Similarly, Column 3 shows that a one unit increase in bank accounts per 1,000 adults leads to a statistically significant decrease in the poverty head count ratio by about $2.02 \%$ of the population. Column 5 shows that a one unit increase in bank branches per 1,000 adults leads to a statistically significant decrease in the poverty head count ratio, which is about $0.96 \%$ of the population.

Next, to analyze the impact of access to finance in the 11 MENA countries of our sample, an interaction term of the dummy variable MENA is added to the regression. In Columns 2, 4 and 6 the dummy variable for the MENA region is interacted with $a t m, b a$ and $b b$, respectively. The interaction terms are statically insignificant, with the exception of the interaction term of $\mathrm{atm}$.

Column 7 shows that the variable acc, a linear combination using the principal component analysis of the three access to finance indicators, ATM machines, bank branches and accounts, is negative and statistically significant. A one unit increase in acc leads to a statistically significant decrease in the poverty head count ratio, about $2.19 \%$ of the population. Column 8 , however, shows that the interaction term of the dummy for the MENA region with the acc indicator has a statistically insignificant impact on the poverty head count ratio.

Table A6 also provides the calculations of the total effect of the availability of ATMs machines, bank branches, accounts and their linear combination on the poverty head count ratio in the MENA region. The results show a statistically insignificant total effect for both the $a t m$ and $b b$. The total effect of bank accounts is negative and statistically significant where a one unit increase in $b a$ leads to a decrease in the poverty head count ratio by about $0.82 \%$ of the population. Finally, the total effect of the variable acc is statistically significant for the group of MENA countries, where a one unit increase in that variable results in a decrease in the poverty head count ratio by about $0.79 \%$ of the population.

The last part of the analysis provides an assessment of the projected achievability of the poverty goal based on four different scenarios: a poverty target of $0 \%, 1.5 \%, 3 \%$ and $5 \%$. Our goal is to answer the question as to whether the MENA countries under study are able
Financial
extreme
poverty

215 
REPS

5,3

to meet these targets by the year 2030 if they depend exclusively on improvement in the financial inclusion services.

Using estimated total effect of the acc index for the MENA region computed in Table A6, the SDG gap analysis for the MENA sample is performed and the results are presented in Table A7 through 10 corresponding to a poverty target of $0 \%, 1.5 \%, 3 \%$ and $5 \%$, respectively. In each table, the Column 3 computes the required SDG growth rate using equation (5), the Column 4 computes the 2030 SDG projection using equation (7) and the Column 5 computes the SDG Gap by subtracting the 2030 targeted poverty level from the poverty projected level for 2030 or Column (4). Column (6) computes the required increase in the financial access index using equation (8) and Column (7) estimates the actual growth in the financial access index using equation (6). Finally, Column (8) computes the 2030 financial access gap by subtracting Column (7) from Column (6).

If we assess the results based on the $0 \%$ target, Table A7 shows that, based on the latest available value for poverty head count ratio, none of the countries in the sample have achieved the targeted level. However, Jordan and Iran are already close to the targeted poverty level with a latest poverty value of 0.1 and 0.2 , respectively. Other countries such as Djibouti and Yemen, are way above the targeted poverty levels with a latest available poverty head count ratio of $22.5 \%$ and $18.8 \%$ of the population, respectively. The annual poverty growth rate would have to fall by $0.3 \%$ and $0.65 \%$, respectively, for them to reach $0 \%$ poverty by 2030 .

As per the results of Column (5), the estimation of the 2030 gap shows that Yemen, Djibouti and Iraq will perform the worst out of the entire MENA sample with a poverty head count ratio gap of $7.81 \%, 3.68 \%$ and $1.65 \%$, of the population, respectively. Those three countries would need to achieve an annual increase in the financial inclusion access index of $0.75 \%, 0.73 \%$ and $0.63 \%$, respectively, to reach $0 \%$ poverty in 2030 . The results of Column (8) show that those three countries will miss the poverty target. Yemen's financial inclusion growth gap is $0.69 \%$, while both Djibouti and Iraq's is $0.60 \%$. On the other hand, Iran and Jordan will be performing the best out of the entire MENA sample with a predicted poverty head count ratio gap of only $0.05 \%$ and $0.09 \%$, of the population, respectively. Those two countries will be able to close the poverty gap in 2030 if they increase the growth rate of the financial inclusion index by $0.59 \%$ and $0.47 \%$, respectively.

Table A8 analyzes the $1.5 \%$ poverty target. Based on the latest available value for poverty head count ratio, the only MENA countries that will not achieve this target are Djibouti, Iraq, Tunisia and Yemen. These countries would require a fall in the annual poverty growth rate of $0.15 \%, 0.03 \%, 0.01 \%$ and $0.15 \%$ to achieve the $1.5 \%$ poverty target by 2030 . The financial inclusion index would have to grow annually by $0.19 \%, 0.04 \%$, $0.02 \%$ and $0.19 \%$, respectively.

Assessing the results based on the $3 \%$ poverty target, according to Table A9, the latest available data shows that all but two of the MENA countries can achieve it; Dibouti and Yemen have a projected poverty gap of $1.32 \%$ and $2.81 \%$, respectively. These two countries would have to achieve a growth of financial inclusion index of $0.11 \%$ and $0.10 \%$, respectively, to close the poverty gap.

Much as they will not achieve the 3\% target, Djibouti and Yemen are the only MENA countries that are not already achieving the most flexible poverty target, $5 \%$, as yet. The projection analysis shows that Djibouti is on track and will be able to close the poverty gap by the year 2030, as shown on Table A10. However, Yemen will miss the target by $2.81 \%$ with a predicted required increase in the financial inclusion index of $0.10 \%$ to close the poverty gap. 


\section{Conclusion}

Using system GMM dynamic panel estimation methodology on annual data for 11 MENA countries and 23 EMs over the period 1990-2017, the study uses several measures of financial inclusion that cover access side of financial services to analyze its impact on eradicating extreme poverty (SDG 1).

The results of the study show that financial access index (or acc index comprising of $a t m s, b a$ and $b b$ ) has a statistically significant impact on reducing extreme poverty for the full sample and the MENA sample. The results confirm that a one-unit increase in the acc index results in a fall in poverty head count ratio by about $2.22 \%$ for the full sample and only about $0.79 \%$ for the MENA sample.

Using the acc index, we then used a gap analysis, using it to predict the ability of MENA to achieve extreme poverty goals by 2030 if they were to depend only on the improvement in financial services and no other factors. The study assesses the impact of the improvements in financial inclusion on the achievability of the SDG 1 against four poverty targets $0 \%$, $1.5 \%, 3 \%$ and $5 \%$. Two of these targets correspond to those assigned by the SDG and the World Bank ( $0 \%$ and $3 \%$, respectively). This analysis incorporates additional targets to make up for any statistical errors the others did not and to give a fuller picture of what is possible and what is probable. The World Bank may be correct to suggest that $3 \%$ worldwide is more realistic than $0 \%$; it also points out that eliminating poverty is a countryby-country endeavor. Four target points allowed this research to illuminate how that endeavor may unfold (World Bank, 2015). The study concludes that if we assess the impact of the improvements in financial inclusion against the most restrictive target of $0 \%$ poverty by 2030 and if the current trends of financial access measures continue, then none of the MENA countries will be able to achieve the poverty goal if they depend only on the improvement in financial access services and no other factors. However, if we assess the impact of the improvements in financial inclusion against the most flexible target of reducing global extreme poverty to no more than $5 \%$ by 2030 , the study concludes that all countries with the exception of one country - Djibouti - will be able to achieve the poverty goal by 2030 if they depend solely on improvements in financial services and no other factors. These results justify dedicating significant resources to such improvements.

Policy considerations can be directed toward developing and promoting the infrastructure needed for the widespread delivery of financial services, especially for the MENA countries lagging behind in achieving the extreme poverty goals. Special attention should be paid to the support of digital financial inclusion. Recent research has emphasized the potential of financial technology (fintech) - such as mobile banking, electronic payments and biometric identification - to alleviate poverty by building resilience and softening the impact of geographic isolation. Various studies show the ways in which faster, cheaper and more secure transactions through digital products help individuals cope with shocks without reducing consumption (Jack and Suri, 2014; Mbiti and Weil, 2014; Suri and Jack, 2016; Munyegera and Matsumoto, 2016; Gurbuz, 2017; El-Zoghbi et al., 2019). Digital financial inclusion has also been shown to encourage investment, help farmers and households manage risks and even close the gender gap in account ownership (United Nations, 2019). It has the potential to benefit governments, too - lowering operational costs while facilitating access to public services. With 100 million "digital natives" under the age of 30 in the MENA region, digital financial inclusion should top governments' povertyreducing strategies.

Yet, the lack of data availability, including on financial technology, in MENA countries remains a major limitation for analyses of fintech's impact on poverty alleviation. As delivery and usage of financial technology is predicted to magnify the impact of financial 
REPS

5,3

inclusion on poverty reduction both directly - as shown in this paper - and indirectly through channels related to other SDGs. Additionally, governments in MENA must take data availability and quality more seriously if they are to reverse the acceleration of extreme poverty in the digital age.

\section{Notes}

1. Formerly Millennium Development Goals, from 2000 to 2015.

2. More specifically Target number 1.1 of SDG 1 .

3. The World Bank goal of ending extreme poverty would reduce the proportion of people living on less than $\$ 1.25$ a day (in 2005 constant dollars, which is $\$ 1.90$ in 2020 dollars) to 3\% by 2030 . The SDG in which it is embedded calls for that indicator to fall to $0 \%$. The World Bank acknowledges that $0 \%$ extreme poverty is an excellent goal, but suggests it is unrealistic, noting that some people whose available money falls below $\$ 1.90$ a day may only experience this circumstance for a short time. It is also the case that reported rates may not be completely reliable. For example, governments are incentivized to underreport poverty rates and may have no knowledge of black market and other cash income. A 3\% rate could be statistically indistinguishable from a $0 \%$ rate.

\section{References}

Abuzayed, B. and Fayoumi, N. (2016), "Bank concentration, institutional quality, and economic growth: empirical evidence from MENA countries", Review of International Business and Strategy, Vol. 26 No. 2, pp. 219-231.

Alvarez de la Campa, A. (2010), "Increasing access to credit through reforming secured transactions in the MENA region”, World Bank Policy Research Working Paper 5613, World Bank, Washington, DC.

Arellano, M. and Bond, S. (1991), "Some tests of specification for panel data: Monte Carlo evidence and an application to employment equations", Review of Economic Studies, Vol. 58, pp. 277-297.

Arellano, M. and Bover, O. (1995), "Another look at the instrumental variable estimation of errorcomponents models", Journal of Econometrics, Vol. 68, pp. 29-51.

Banerji, A. and Humphreys, C. (2003), "Better governance for development in the Middle East and North Africa: enhancing inclusiveness and accountability”, World Bank, ISBN: 978-0-8213-56357, doi: 10.1596/0-8213-5635-6.

Beck, T., Pamuk, H., Ramrattan, R. and Uras, B.R. (2018), "Payment instruments, finance and development”, Journal of Development Economics, Vol. 133, pp. 162-186.

Blundell, R. and Bond, S. (1998), "Initial conditions and moment restrictions in dynamic panel data models", Journal of Econometrics, Vol. 87, pp. 115-143.

Blundell, R.W., Bond, S.R. and Windmeijer, F. (2000), "Estimation in dynamic panel data models: improving on the performance of the standard GMM estimatori”, in Baltagi, B. (Ed.), Nonstationary Panels, Panel Cointegration, and Dynamic Panels, Advances in Econometrics 15, JAI Press, Elsevier Science.

Caselli, F., Esquivel, G. and Lefort, F. (1996), "Reopening the convergence debate: a new look at crosscountry growth empirics", Journal of Economic Growth, Springer, Vol. 1 No. 3, pp. 363-389.

Crespo Cuaresma, J., Fengler, W. and Kharas, H. (2018), "Will the sustainable development goals be fulfilled? Assessing present and future global poverty”, Palgrave Communications, Vol. 4 No. 1, p. 29, doi: 10.1057/s41599-018-0083-y.

Cumming, D., Johan, S. and Zhang, M. (2014), "The economic impact of entrepreneurship: comparing international datasets", Corporate Governance: An International Review, Vol. 22 No. 2, pp. $162-178$. 
Demirguc-Kunt, A. and Klapper, L. (2013), "Measuring financial inclusion: explaining variation in use of financial services across and within countries", Brookings Papers on Economic Activity, Vol. 2013 No. 1, pp. 279-321.

El-Zoghbi, M., Holle, N. and Soursourian, M. (2019), Emerging Evidence on Financial Inclusion: Moving from Black and White to Color, CGAP, World Bank, Washington, DC, available at: www.cgap. org/sites/default/files/publications/2019_07_FocusNote_Emerging_Evidence.pdf

Emara, N. (2014), "Income elasticity and the gender gap: a challenging MDG for the MENA countries", Review of Middle East Economics and Finance, Vol. 10 No. 3, pp. 263-292.

Emara, N. and El Said, A. (2015), "Revisiting sovereign ratings, capital flows, and financial contagion in emerging markets", World Journal of Applied Economics, Vol. 1 No. 2, pp. 3-22.

Emara, N. and Moore, R. (2014), "Effect of income elasticity on MDG health indicators: the case of MENA countries", Review of Middle East Economics and Finance, Vol. 10 No. 1, pp. 53-73.

Emara, N. and El Said, A. (2020), "Financial inclusion and economic growth: the role of governance in selected MENA countries. Munich personal RePEc archive", MPRA Paper No. 99257.

Gurbuz, A. (2017), "Does mobile money mobilize savings? Yes", Unpublished, available at: https:// blogs.worldbank.org/impactevaluations/does-mobile-money-mobilize-savings-yes-guestpost-alev-gurbuz

Hamdi, H. and Hakimi, A. (2015), "Did banks and financial markets developments lead to economic growth in MENA region?”, Evidence from Dynamic panel data estimation, available at: https:// mpra.ub.uni-muenchen.de/64310/

Holtz-Eakin, D., Newey, W. and Rosen, H. (1988), "Estimating vector autoregressions with panel data", Econometrica, Vol. 56, pp. 1371-1395.

Honohan, P. (2004), "Financial development, growth and poverty: how close are the links?", World Bank Policy Research Working Paper 3203, World Bank, Washington, DC.

Jack, W. and Suri, T. (2014), "Risk sharing and transactions costs: evidence from Kenya's mobile money revolution", The American Economic Review, Vol. 104 No. 1, pp. 183-223.

Kitazawa (2003), "Estimation of persistence in log-volatility using panel data", Applied Financial Economics, Vol. 13 No. 6, pp. 463-472.

Klapper, L., El-Zoghbi, M., (2016), and J. and Hess, Achieving the Sustainable Development Goals: The Role of Financial Inclusion, CGAP, Washington, DC.

Mbiti, I. and Weil, D.N. (2014), "Mobile banking: the impact of M-PESA in Kenya”, Working paper No. 17129, National Bureau of Economic Research, doi: 10.3386/w17129.

Munyegera, G.K. and Matsumoto, T. (2016), "Mobile money, remittances, and household welfare: panel evidence from rural Uganda", World Development, Vol. 79, pp. 127-137, doi: 10.1016/j. worlddev.2015.11.006.

Ncube, M., Anyanwu, J.C. and Hausken, K. (2013), "Inequality, economic growth, and poverty in the Middle East and North Africa (MENA)", African Development Bank Working Paper Series 195, African Development Bank, Tunis.

Neaime, S. and Gaysset, I. (2018), "Financial inclusion and stability in MENA: evidence from poverty and inequality", Finance Research Letters, Vol. 24, pp. 230-237.

Panda, M. and Ganesh-Kumar, A. (2007), "Impact of economic growth on achieving MDGs", Report submitted to UN Economic and Social Commission for Asia and Pacific, Bangkok.

Pearce, D. (2011), Financial Inclusion in the Middle East and North Africa, The World Bank Middle East and North Africa Region, Financial and Private Sector Development Unit.

Sharma, D. (2016), "Nexus between financial inclusion and economic growth: evidence from the emerging Indian economy", Journal of Financial Economic Policy, Vol. 8 No. 1, pp. 13-36.

Suri, T. and Jack, W. (2016), "The long-run poverty and gender impacts of mobile money", Science, Vol. 354 No. 6317, pp. 1288-1292, doi: 10.1126/science.aah5309. 
REPS

5,3

United Nations (2019), "Inter-agency Task Force on Financing for Development, Financing for Sustainable Development Report”, United Nations, New York, NY, available at: https:// developmentfinance.un.org/fsdr2019

World Bank (2015), “A Measured Approach To Ending Poverty And Boosting Shared Prosperity", World Bank, Washington, DC.

World Bank (2018), "Poverty and Shared Prosperity 2018: Piecing Together the Poverty Puzzle”, World Bank, Washington, DC.

Yafee, R. (2003), “A primer for panel data analysis”, Connect: Information Technology at NYU, (Fall), pp. 1-11.

\section{Further reading}

Acemoglu, D., (2012), and J. and Robinson, Why Nations Fail: The Origins of Power, Prosperity, and Poverty, Crown Publishers, New York, NY.

Banerjee, A. and Newman, A. (1994), "Poverty, incentives and development", American Economic Review Papers and Proceedings, Vol. 84 No. 2, pp. 211-215.

Banerjee, A. and Duflo, E. (2011), Poor Economics: A Radical Rethinking of the Way to Fight Global Poverty, PublicAffairs, New York, NY.

Beck, T., Demirguc-Kunt, A. and Levine, R. (2007), "Finance, inequality, and the poor", Journal of Economic Growth, Vol. 12 No. 1, pp. 27-49.

Brune, L., Gine, X., Goldberg, J. and Yang, D. (2015), "Facilitating savings for agriculture: Field experimental evidence from Malawi”, NBER Working Paper 20946, Mass.: National Bureau of Economic Research, Cambridge.

Burgess, R. and Pande, R. (2005), "Do rural banks matter? Evidence from the Indian social banking experiment", American Economic Review, Vol. 95 No. 3, pp. 780-795.

Cuberes, D. and Teignier, M. (2015), "Aggregate effects of gender gaps in the labor market: a quantitative estimate", Journal of Human Capital, Vol. 10 No. 1.

Dupas, P. and Robinson, J. (2013), "Savings constraints and microenterprise development: evidence from a field experiment in Kenya", American Economic Journal: Applied Economics, Vol. 5 No. 1, pp. 163-192.

Gable, S. Lofgren, H. and Osorio Rodarte, I. (2015), "Trajectories for sustainable development goals: Framework and country applications".

Greenwood, J. and Jovanovic, B. (1990), "Financial development, growth, and the distribution of income", Journal of Political Economy, Vol. 98 No. 5, Part 1, pp. 1076-1107.

Karlan, D., Ratan, A.L. and Zinman, J. (2014), "Savings by and for the poor: a research review and agenda", Review of Income and Wealth, Vol. 60 No. 1.

Kim, D.-W., Yu, J.-S. and Hassan, M.K. (2018), "Financial inclusion and economic growth in OIC countries", Research in International Business and Finance, Vol. 43 No. C, pp. 1-14.

Kirk, M., Steele, J., (2011), and L. and Crow, Connected Agriculture-the Role of Mobile, Accenture, London.

Measuring Progress from 1990 to 2017 and projecting attainment to 2030 of the health-related Sustainable Development Goals for 195 countries and territories: a systematic analysis for the Global Burden of Disease Study (2018).

Nicolai, S., Hoy, C., Berliner, T. and Aedy, T. (2015), Projecting Progress: Reaching the SDGs by 2030, Overseas Development Institute, London.

Page, L. and Pande, R. (2018), "Ending global poverty: why money isn't enough”, Journal of Economic Perspectives, Vol. 32 No. 4, pp. 173-200.

Pande, R., Cole, S., Sivasankaran, A., Bastian, G., (2012), and K. and Durlacher, "Does poor people's access to formal banking services raise their income?", EPPI-Centre, Social Science Research Unit, Institute of Education, University of London, London. 
Park, C.-Y. and Mercado, R.V. (2015), "Financial inclusion, poverty, income inequality in developing asia”, Asian Development Bank Economics Working Paper 426, Asian Development Bank, Manila.

Park, C.-Y. and Mercado, R.V. (2018), "Financial inclusion, poverty, and income inequality", Singapur Economic Review, Vol. 63 No. 1.

Financial inclusion and

extreme

poverty

Priyanka, S., Xu, K. and Evans, D.B. (2011), "Impact of out-of-pocket payments for treatment of noncommunicable diseases in developing countries: a review of literature", World Health Organization Discussion Paper 2, World Health Organization, Geneva.

Seven, Ü. and Coskun, Y. (2016), "Does financial development reduce income inequality and poverty? Evidence from emerging countries", Emerging Markets Review, Vol. 26 No. C, pp. 34-63.

World Bank (2014), "Global Financial Development Report 2014: financial inclusion”, World Bank, Washington, DC.

\section{Corresponding author}

Noha Emara can be contacted at: nemara@camden.rutgers.edu 


\section{REPS Appendix}

5,3

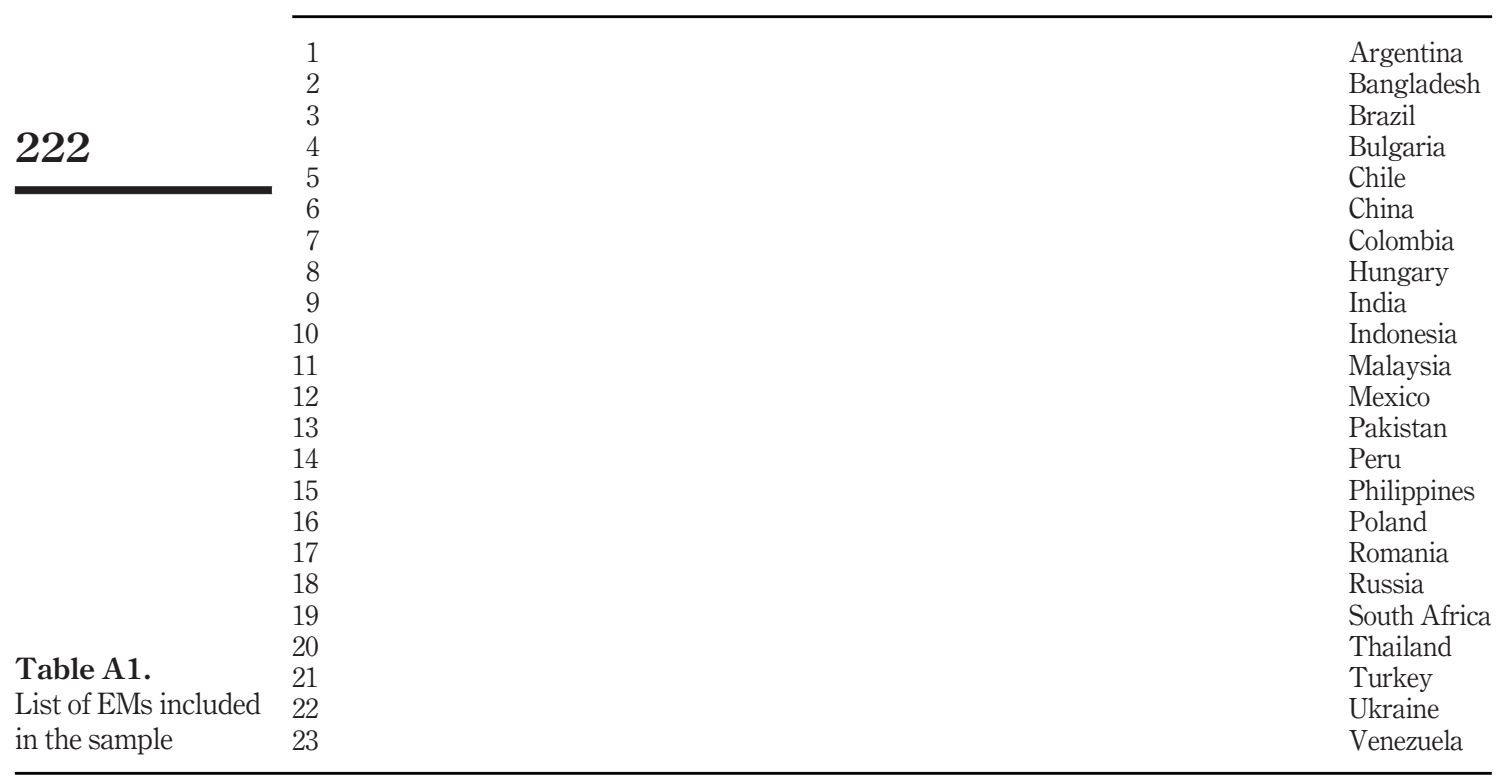

\begin{tabular}{lrl}
\cline { 2 - 3 } & 1 & \\
& 2 & Algeria \\
& 3 & Djibouti \\
& 4 & Egypt \\
& 5 & Iran \\
& 6 & Iraq \\
Table A2. & 7 & Israel \\
List of MENA & 8 & Jordan \\
included in the & 9 & Morocco \\
sample & 10 & Tunisia \\
& 11 & West Bank and Gaza \\
\hline
\end{tabular}




\begin{tabular}{|c|c|c|c|c|c|}
\hline $\begin{array}{l}\text { Variable } \\
\text { name }\end{array}$ & WDI definition & $\begin{array}{l}\text { Unit of } \\
\text { measurement }\end{array}$ & Data source & Abbreviation & inclusion and \\
\hline Poverty & $\begin{array}{l}\text { Poverty headcount ratio at } \$ 1.90 \text { a day } \\
(2011 \text { PPP) ( } \% \text { of population). Increase in } \\
\text { poverty gap at } \$ 1.90 \text { ( } \$ 2011 \text { PPP) poverty } \\
\text { line due to out-of-pocket health care } \\
\text { expenditure, as a percentage of the } \$ 1.90 \\
\text { poverty line }\end{array}$ & $\%$ & $\begin{array}{l}\text { World development } \\
\text { indicators }\end{array}$ & pov & poverty \\
\hline Growth & $\begin{array}{l}\text { Annual percentage growth rate of GDP at } \\
\text { market prices based on constant local } \\
\text { currency. Aggregates are based on constant } \\
2010 \text { US dollars. GDP is the sum of gross } \\
\text { value added by all resident producers in the } \\
\text { economy plus any product taxes and minus } \\
\text { any subsidies not included in the value of } \\
\text { the products. It is calculated without } \\
\text { making deductions for depreciation of } \\
\text { fabricated assets or for depletion and } \\
\text { degradation of natural resources }\end{array}$ & t & $\begin{array}{l}\text { World development } \\
\text { indicators }\end{array}$ & $g d p g r$ & \\
\hline Inflation & $\begin{array}{l}\text { Change in the log of consumer price index } \\
(2010=100) \text { (authors computation). } \\
\text { Consumer price index reflects changes in } \\
\text { the cost to the average consumer of } \\
\text { acquiring a basket of goods and services } \\
\text { that may be fixed or changed at specified } \\
\text { intervals such as yearly. The Laspeyres } \\
\text { formula is generally used. Data are period } \\
\text { averages }\end{array}$ & $\%$ & $\begin{array}{l}\text { World development } \\
\text { indicators }\end{array}$ & infl & \\
\hline Trade & $\begin{array}{l}\text { Trade is the sum of exports and imports of } \\
\text { goods and services measured as a share of } \\
\text { gross domestic product }\end{array}$ & $\%$ & $\begin{array}{l}\text { World development } \\
\text { indicators }\end{array}$ & tra & \\
\hline $\begin{array}{l}\text { Population } \\
\text { growth }\end{array}$ & $\begin{array}{l}\text { Change in the log of population (Total). } \\
\text { Annual population growth rate for year } t \text { is } \\
\text { the exponential rate of growth of midyear } \\
\text { population from year } t \text { - } 1 \text { to } t \text {, expressed as } \\
\text { a percentage. Population is based on the de } \\
\text { facto definition of population, which counts } \\
\text { all residents regardless of legal status or } \\
\text { citizenship }\end{array}$ & $\%$ & $\begin{array}{l}\text { World development } \\
\text { indicators }\end{array}$ & $p o p g r$ & \\
\hline Mobile & $\begin{array}{l}\text { Mobile cellular subscriptions (per } 100 \\
\text { people). Mobile cellular telephone } \\
\text { subscriptions are subscriptions to a public } \\
\text { mobile telephone service that provide } \\
\text { access to the PSTN using cellular } \\
\text { technology. The indicator includes (and is } \\
\text { split into) the } \\
=\text { purchasing power parity; PSTN = public sv }\end{array}$ & switched tele & $\begin{array}{l}\text { World development } \\
\text { indicators }\end{array}$ & $m o b$ & $\begin{array}{r}\text { Table A3. } \\
\text { Definitions of } \\
\text { economic variables }\end{array}$ \\
\hline
\end{tabular}


REPS
5,3

224

Bank accounts per 1,000 adults

Bank branches per 100,000 adults

Table A4.

Definitions of financial access variables

Access index

\begin{tabular}{lllll}
\hline Indicator & Definition & Periodicity & Source & Abbreviation \\
\hline $\begin{array}{l}\text { ATMs per } \\
\text { 100,000 adults }\end{array}$ & $\begin{array}{l}\text { ATMs are computerized } \\
\text { telecommunications devices that }\end{array}$ & $1990-2017$ & $\begin{array}{l}\text { World development } \\
\text { indicators }\end{array}$ & atm
\end{tabular}

provide clients of a financial institution with access to financial transactions in a public place

Number of depositors with commercial banks per 1,000 adults. Depositors with commercial banks are the reported number of deposit account holders at commercial banks and other resident banks functioning as commercial banks that are resident nonfinancial corporations (public and private) and households. For many countries data cover the total number of deposit accounts due to lack of information on account holders. The major types of deposits are checking accounts, savings accounts and time deposits

\section{Commercial bank branches are} retail locations of resident commercial banks and other resident banks that function as commercial banks that provide financial services to customers and are physically separated from the main office but not organized as legally separated subsidiaries 1990-2017 $\begin{aligned} & \text { World development } b a \\ & \text { indicators }\end{aligned}$ 1990-2017 $\begin{aligned} & \text { World development } \quad b b \\ & \text { indicators }\end{aligned}$ past three indicators

Author computation 


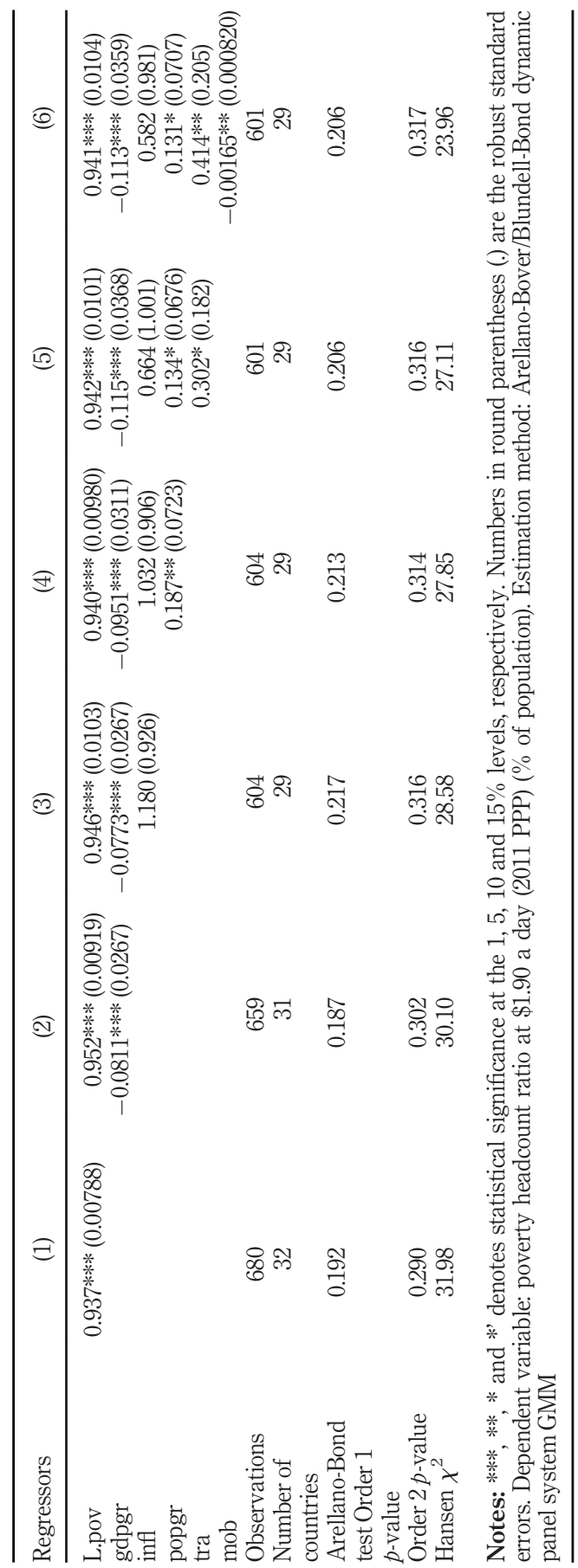

Financial inclusion and extreme poverty

225

Table A5. Extreme poverty: the benchmark model 


\section{REPS \\ 5,3}

226
Table A6.

Extreme poverty and financial access measures

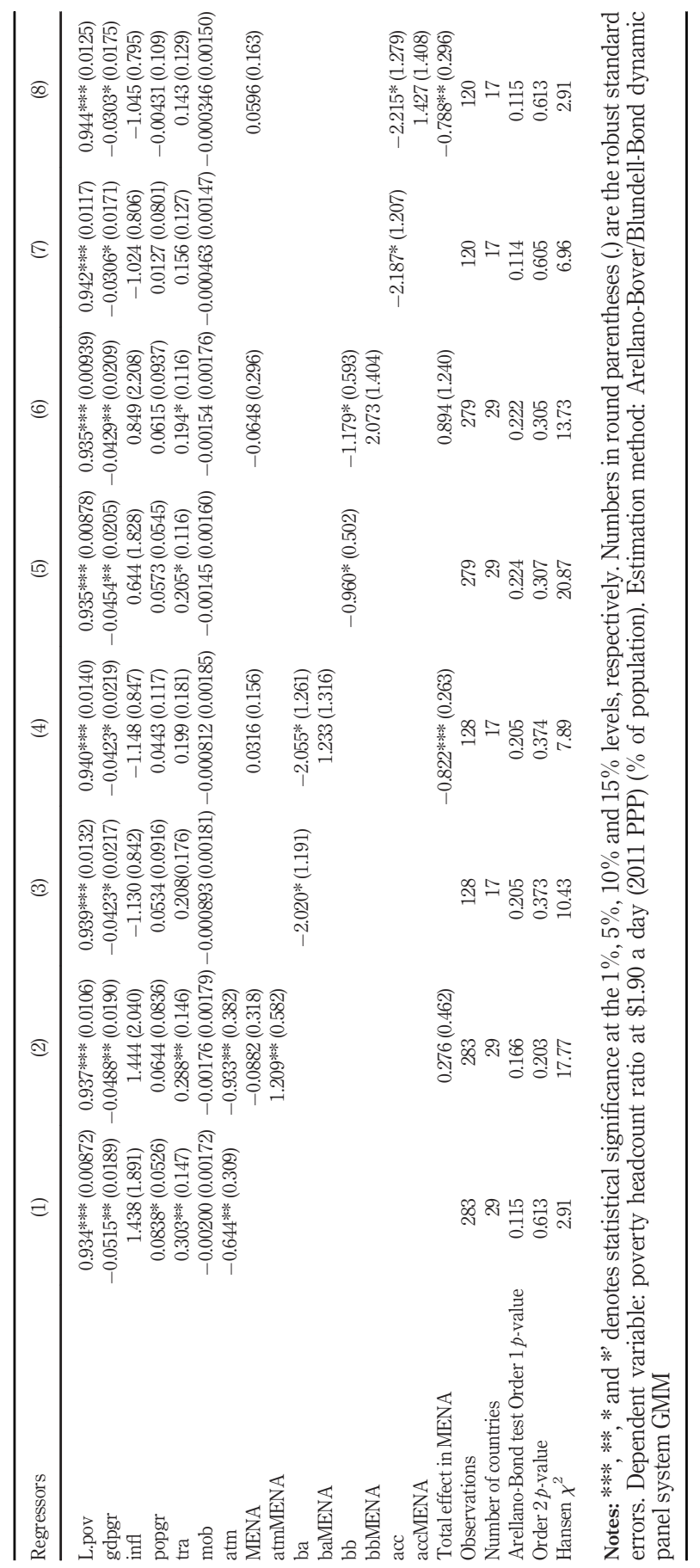




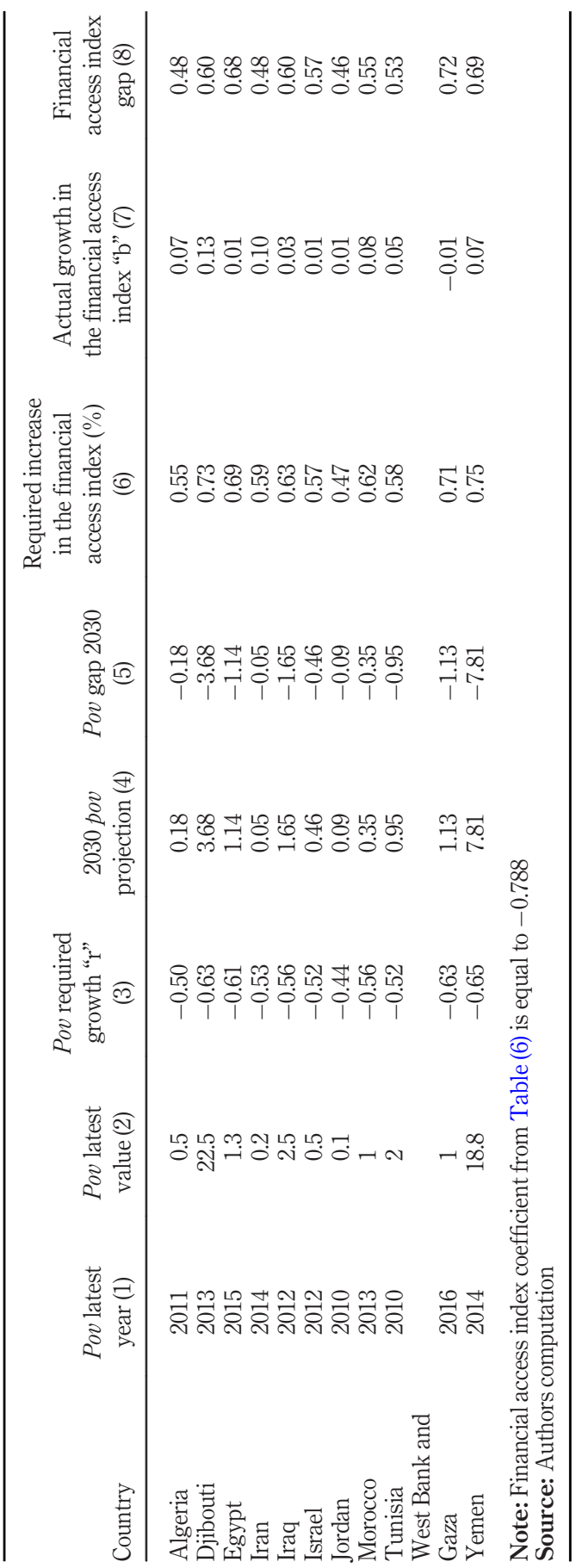

Financial inclusion and extreme poverty

227

Table A7. Extreme poverty and financial access gap analysis in MENA region - assessment against the UN's $0 \%$ poverty target 


\section{REPS}

5,3

\section{8}

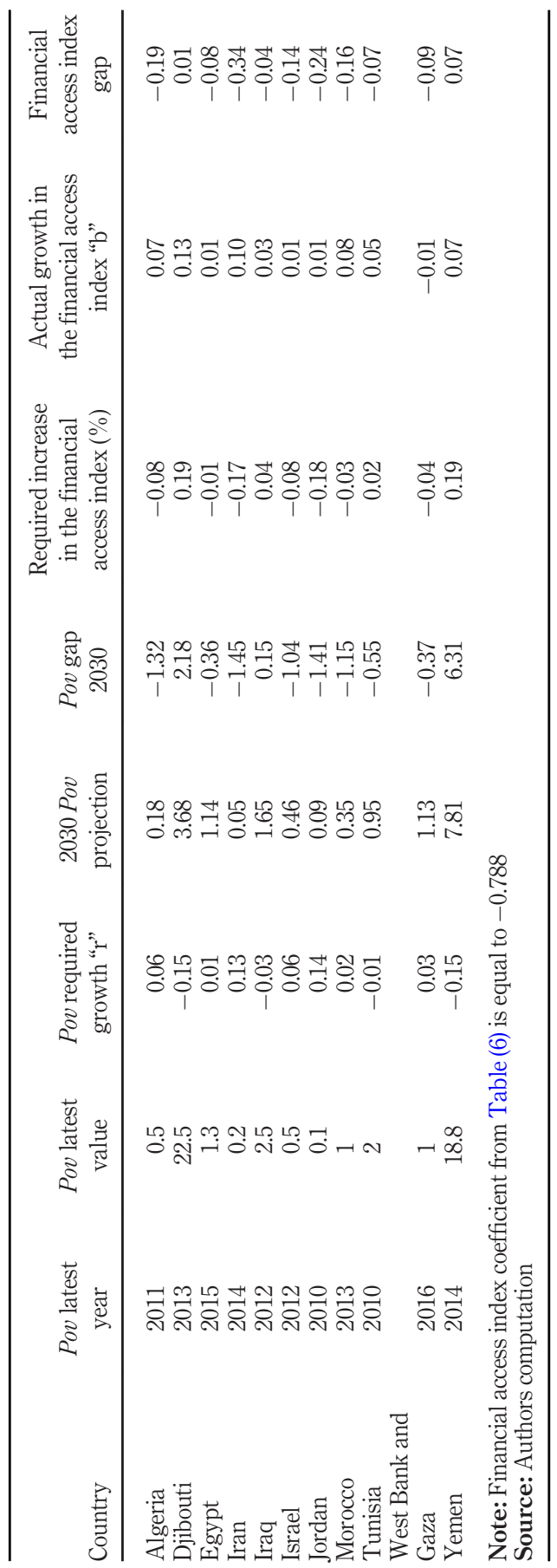

Table A8.

Extreme poverty and financial access gap analysis in MENA region - assessment against the $1.5 \%$ poverty target

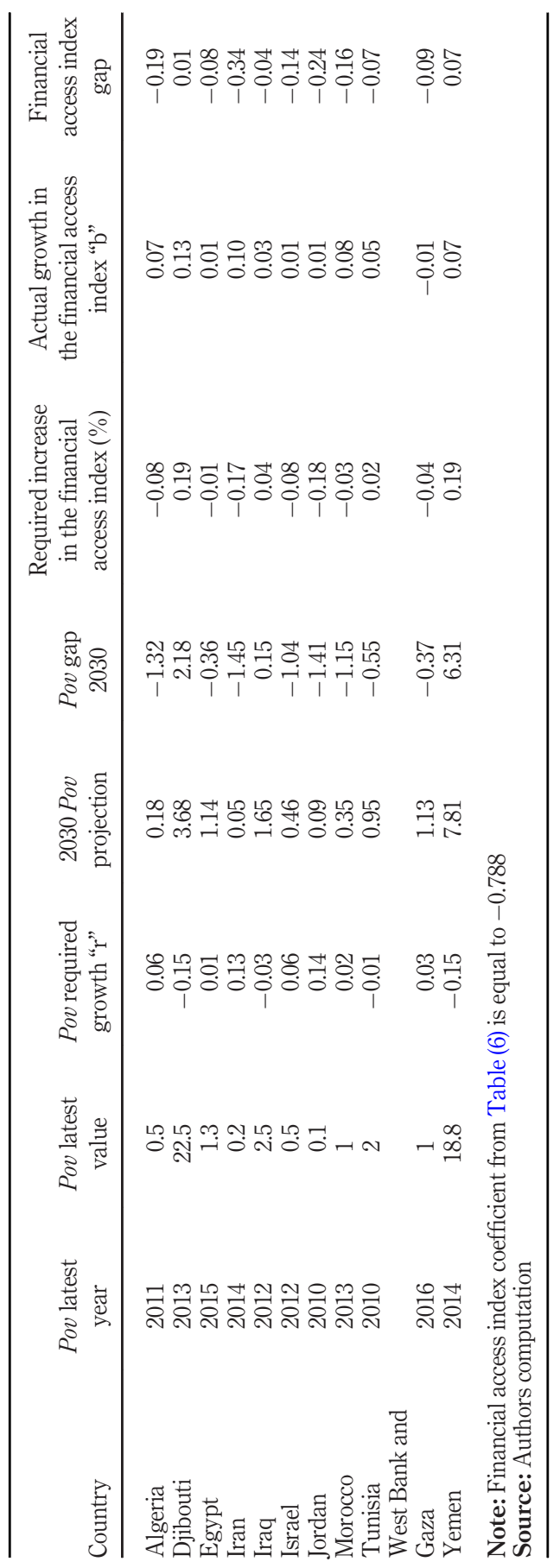




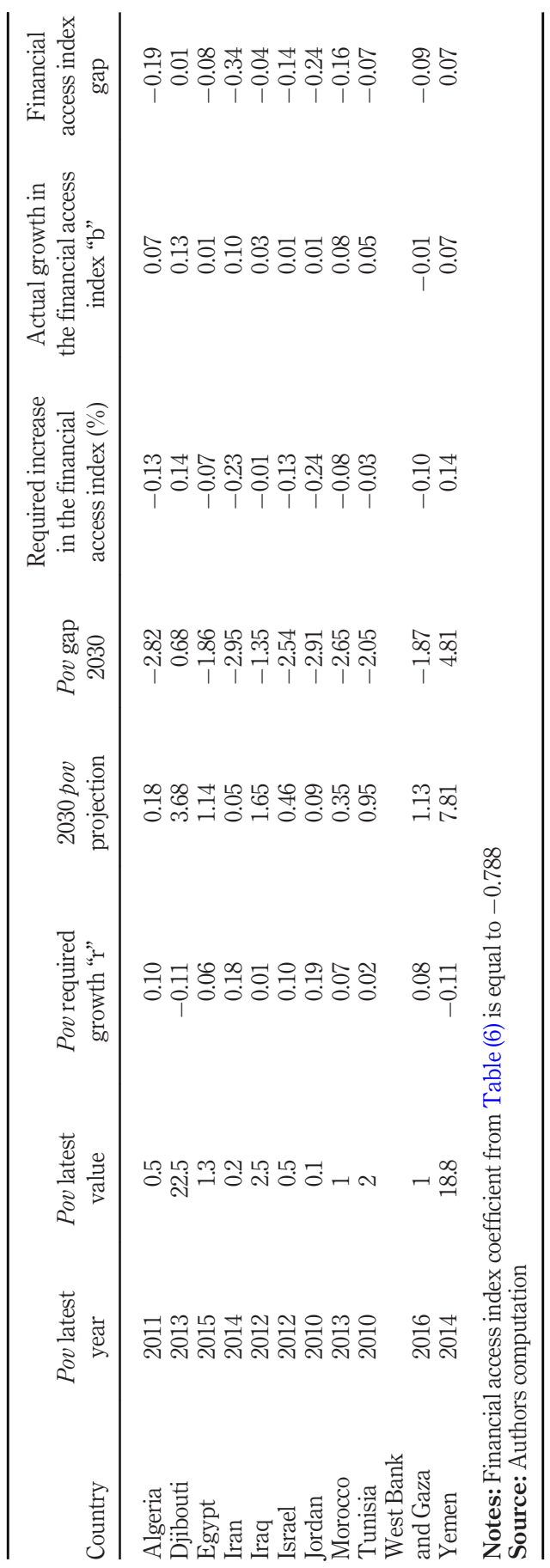

Financial inclusion and extreme poverty

229

Table A9.

Extreme poverty and financial access gap analysis in MENA region - assessment against the $3 \%$ poverty target 


\section{REPS}

5,3

230

Table A10.

Extreme poverty and financial access gap analysis in EMs assessment against the $5 \%$ poverty target

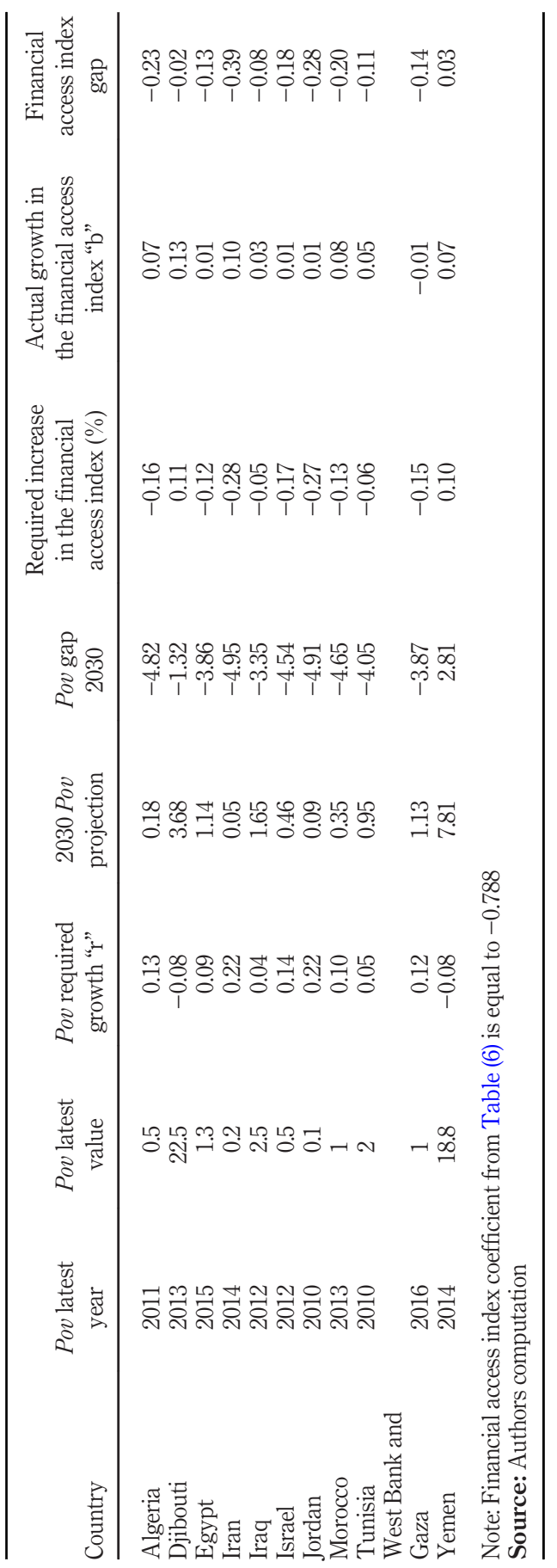

